значною мірою залежить від державної підтримки, однак насамперед від власного прагнення до саморозвитку і самореалізації.

1. Бацевич Ф. С. Основи комунікативної лінгвістики : [підручник]/ Ф. С. Бацевич. - К. : Академія, 2004. - 344 с. 2. Валгина Н. С. Теория текста: [учебн. пособие]/ Н. С. Валгина. - М. : Логос. 2003. - 280 с. - Режим доступу 5.06.2012: http://www.evatist.ru/text14/ 01.htm. - Загол. 3 екрану. - Мова рос. 3. Васильсва Т. А. Діяльність банківських установ на ринку інноваційного інвестування: методологічні засади : дис. ... доктора економ. наук : спец. 08.00.08- «Гроші, фінанси і кредит» [Текст]/ Т. А. Васильєва; ДВНЗ «УАБС НБУ».- Суми. - 2008. - 504 с. 4. Караулов Ю. Н. Русский язык и языковая личность / Ю. Н. Караулов. - М. : ЛКИ, УРСС Эдиториал, 2010. - 264 с. 5. Карпухина Н. М. Лексико-семантические процессы в русской терминологии товарно-денежного обращения : автореф. дис. на соискание науч. степени канд. філол. наук: 10.02 .01 /Н. М. Карпухина; Московский гос. област. унт. - М., 2007. - 34 с. 6. Козьменко О. В. Страховий ринок України у контексті сталого розвитку : [монографія]/ О. В. Козьменко. - Суми : ДВНЗ «УАБС НБУ», 2008. - 352 с. 7. Козьменко С. М. Розвиток методичних підходів до формалізації структури вітчизняного фінансового ринку/ С. М. Козьменко, С. В. Лєонов // Вісник Університету банківської справи Національного банку України. - 2010. - № 2. - С. 3-9. 8. Лєонов С. В. Інвестиційний потенціал банківської системи України [Текст]: монографія / С. В. Лєонов. - Суми : ДВНЗ «УАБС НБУ», 2009. - 375 с. 9. Попова Н. О. Структурносемантичні особливості новітніх лексичних запозичень 3 англійської в українську мову (90-і pp. XX ст. - початок XXI ст.) : автореф. дис.на здобуття наук.ступеня канд. філол. наук: $10.02 .01 /$ Н. О. Попова; Запоріз. держ. ун-т. - Запоріжжя, 2005. - 19 с. 10. Семеног О. Українська мова : професійне спрямування - біржова діяльність : практикум : [навч. посіб. для студ. біржових спец. вищ. навч. закл.] / Олена Семеног, Валентина Гордієнко - К. : Бії Граф, 2007. - 220 с. 11. Сербенська О. Мовлене слово у життєсвіті Івана Франка. [Електронний ресурс] - Режим доступу: http://journ.Inu.edu.ua/publications/zbirnyk07/Zbirnyk07_ Serbenskhtm. 12. Словник іншомовних слів / за ред. О. С. Мельничука. - К., 1975. - 776 с. 13. Школьник І. О. Фінансовий ринок України: сучасний стан та стратегія розвитку: [монографія]/ I. О. Школьник. - Суми : Мрія, УАБС НБУ, 2008. - 348 с. 14. Ярощук І. Діловий дискурс фахівця економічного профілю як комунікативне явище [Електронний ресурс]Режим доступу: journal.mandrivets.com/images/file/Jaroshchuk_2012_3.pdf.

Тетяна Філатьєва

\title{
АНАЛІЗ РЕЗУЛЬТАТІВ ДОСЛІДНО-ЕКСПЕРИМЕНТАЛЬНОЇ РОБОТИ З ПІДГОТОВКИ МАЙБУТНІХ ФАХІВЦІВ У ГАЛУЗІ МИСТЕЦТВА ДО ХУДОЖНЬО-ПЕДАГОГІЧНОЇ ДІЯЛЬНОСТІ В ПОЗАШКІЛЬНИХ ЗАКЛАДАХ ОСВІТИ
}

Філатьєва Т. В. Аналіз результатів дослідно-експериментальної роботи 3 підготовки майбутніх фахівців у галузі мистецтва до художньо-педагогічної діяльності в позашкільних закладах освіти.

У статті підсумовуються результати дослідно-експериментальної роботи, яка проводилась у вищих художньо-педагогічних навчальних закладах. Авторка визначає 
критерії та показники готовності до художньо-педагогічної діяльності в позашкільних закладах освіти, розробляє та впроваджує в роботу комплекс діагностичних методик.

Ключові слова: аналіз, дослідно-експериментальна робота, позашкільні заклади освіти, критерії та показники готовності, фахівці у галузі мистецтва.

Филатьева Т. В. Анализ результатов опытно-экспериментальной работы по подготовке будущих специалистов в области искусства к художественнопедагогической деятельности во внешкольных учебных заведениях.

В статье подытоживаются результаты опытно-экспериментальной работы, которая проводилась в высших художественно-педагогических учебных заведениях. Автор определяет критерии и показатели готовности к художественно-педагогической деятельности во внешкольных учебных заведениях, разрабатывает и внедряет в работу комплекс диагностических методик.

Ключевые слова: анализ, опытно-экспериментальная работа, внешкольные учебные заведения, критерии и показатели готовности, специалисты в области искусства.

Filatyeva T. V. Analysis of doslidno-eksperimental'noy job performances on preparation of future specialists in industry of art to to artistically pedagogical to activity in out-of-school establishments of education.

Doslidno-eksperimental'noy job which was conducted in more high artistically pedagogical educational establishments performances are summarized in the article. An author determines criteria and indexes of readiness to to artistically pedagogical to activity in out-ofschool establishments of education, develops and inculcates the complex of diagonostichnikh in work

Key words: analysis, experimental work, out-of-school educational establishments, criteria and indexes of readiness, specialists in area of art.

Ефективна підготовка фахівців у галузі мистецтва до художньо-педагогічної діяльності в позашкільних навчально-виховних закладах освіти можлива завдяки вдосконаленню навчально-виховного процесу у вищому навчальному закладі. Визначення педагогічних умов, що забезпечують ефективність досліджуваного процесу, здійснювалося 3 урахуванням відповідних теоретичних засад, результатів констатувального етапу експерименту, експертної оцінки педагогів-практиків позашкільних закладів та фахівців вищих закладів освіти мистецького спрямування.

Meта статmі - проаналізувати результати дослідно-експериментальної роботи 3 формування готовності майбутніх фахівців у галузі мистецтва до художньо-педагогічної діяльності в позашкільних закладах освіти художньо-естетичного спрямування.

До питань організації та аналізу науково-педагогічної, дослідної роботи зверталися Ю. Бабанський, В. Давидов, В. Загвязинський, В. Романчиков, М. Скаткін, А. Філіпенко та ін.

До початку формувального експерименту нами були підготовлені необхідні матеріали: структура системи роботи з питань підготовки фахівців у галузі мистецтва до художньо-педагогічної діяльності в позашкільних закладах освіти, зміст анкет, бесід, контрольно-творчих завдань, діагностичні методики, спецкурс «Педагогіка позашкільних закладів освіти» та методичні поради щодо його реалізації, методичнопрактичні рекомендації викладачам мистецьких дисциплін «Іторія образотворчого мистецтва», «Методика викладання образотворчого мистецтва», «Практика 3 вивчення творів мистецтва». 
Задля отримання підсумкової інформації про рівень готовності майбутніх педагогів до художньо-педагогічної діяльності в позашкільних закладах освіти художньо-естетичного напрямку ми використовували такі методи: аналіз результатів навчально-виховної та художньо-творчої діяльності студентів; аналіз документів, спостереження; діагностичні зрізи, аналіз результатів творчих завдань, які виконували студенти, оцінювання їх експертною комісією; статистичні методи математичного оброблення даних результатів експериментальної роботи.

Спостереження за респондентами підтверджують думку, що впровадження знань, умінь та навичок художньо-педагогічної діяльності в позашкільному закладі освіти підвищують у них професійний рівень готовності. Порівняльно-зіставний аналіз проводився відповідно до кожного 3 трьох компонентів готовності до художньопедагогічної діяльності в позашкільному закладі освіти на основі методик, що використовувалися на діагностувальному етапі експериментальної роботи.

Дані підсумкового зрізу порівнювалися між собою та 3 результатами констатувального етапу дослідження відповідно до кожного зі структурних компонентів готовності майбутніх фахівців у галузі мистецтва до художньо-педагогічної діяльності в системі позашкільної освіти.

Переходимо до аналізу експерименту. У контрольних групах навчання й виховання здійснювалося традиційно, без додаткової інформації стимулювання. У цих групах відповідно до обраних нами критеріїв щодо рівнів готовності та іiі показників було проведено контрольні завдання, бесіди, діагностування, анкетування задля визначення підсумкових відомостей.

Головне завдання формувального етапу експерименту полягало в тому, щоб з'ясувати, як впливає на якість готовності фахівців у галузі мистецтва до художньопедагогічної діяльності в системі позашкілля методика роботи, обрана та обгрунтована нами, і програма впровадження підготовки до художньо-педагогічної діяльності в позашкільних закладах у навчально-виховний процес ВНЗ.

Підгрунтям для аналізу результативності дослідно-експериментальної роботи стали розроблені нами критерії оцінювання готовності студентів художніх спеціальностей до художньо-педагогічної роботи в позашкільних закладах художньоестетичного напрямку. Згідно 3 цими критеріями вимірювалися основні структурні компоненти та показники окресленої готовності: мотиваційно-ціннісний критерій рівень потреби в художньо-педагогічній діяльності встановлювався за результатами бесіди, інтерв'ю, анкетування, у ході аналізу продуктів творчої діяльності студентів; когнітивний критерій - діагностична карта, анкетування, бесіда; поведінковий критерій- аналіз творчих рефлексивних завдань, анкетування, спостереження за роботою студентів під час педагогічної практики, у процесі викладання фахових дисциплін.

Отже, для оптимальної характеристики студентів контрольної та експериментальної груп подаємо вихідні дані рівнів готовності до художньопедагогічної діяльності в системі позашкілля за трьома діагностичними критеріями.

Дослідження результатів упровадження педагогічних умов підготовки майбутніх педагогів-позашкільників до художньо-педагогічної діяльності проводилося через порівняння результатів підсумкового діагностування студентів експериментальних та контрольних груп на основі комплексу методик: бесіда, спостереження, аналіз результатів творчої діяльності, аналіз документів, анкетування, діагностика, методи математичної статистики.

Комплекс діагностувальних методик, які взаємодоповнюють одна одну, дозволив одержати об’єктивні та вірогідні дані за показниками критеріїв готовності студентів 
мистецьких факультетів до художньо-педагогічної діяльності в позашкільних навчально-виховних закладах художньо-естетичного напрямку.

У контрольних та експериментальних групах було запроваджено ідентичні методики. Дані засвідчили, що практично зросли рівні готовності фахівців у галузі мистецтва до художньо-педагогічної діяльності в позашкільних навчально-виховних закладах і в контрольних, і в експериментальних групах майже за всіма критеріями досліджуваної готовності. У контрольних групах помітно незначний відсотковий приріст за всіма показниками готовності студентів до художньо-педагогічної діяльності в системі позашкілля за кінцевими даними експерименту. Аналіз результатів досліджень показує, що найменший відсотковий приріст спостерігається в рівнях за показниками когнітивного критерію, оскільки спеціальної підготовки та цілеспрямованої роботи над формуванням знань, умінь та навичок до художньо-педагогічної діяльності в позашкільних установах в контрольних групах не проводилося.

За результатами експерименту зазначимо, що за мотиваційно-ціннісним та поведінковим критеріями відсотковий приріст характерний для середнього та критичного рівнів готовності до досліджуваного виду діяльності, що, зі свого боку, зменшило показники низького рівня.

В експериментальних групах помітне зростання кількості студентів, рівень знань, умінь та навичок яких ми оцінили як високий за всіма критеріями професійної готовності майбутніх педагогів-позашкільників до художньо-педагогічної діяльності.

Динаміка зростання за даними трьох критеріїв готовності до художньо-педагогічної діяльності в позашкільних закладах освіти художньо-естетичного напрямку в експериментальних групах досить помітна й, на нашу думку, достатня для якісної фахової підготовки майбутніх педагогів-позашкільників. Так, за всіма критеріями значно знизилася кількість студентів низького рівня готовності (хоча на початку експерименту ми мали такі відсоткові дані: мотиваційно-ціннісний критерій - 15,9\%, когнітивний - 29,5\%, поведінковий - 25,3\%), що підтверджує ефективність проведеної в цих групах роботи.

У ході експерименту ми спостерігали поступове зростання рівня активності виконання студентами художньо-творчої та педагогічної діяльності під час педагогічної практики в позашкільних закладах художньо-естетичного напрямку, помітно зріс рівень інтелектуально-творчої підготовки фахівців, які з питомим інтересом ставилися до науково-дослідної роботи з проблем позашкільної педагогіки, розв'язували різні художньо-педагогічні завдання в межах фахових дисциплін.

Високий відсотковий результат оволодіння студентами експериментальних груп знаннями, уміннями та навичками в галузі позашкільної педагогіки досягнуто завдяки усвідомленим особистісним потребам студентів у художньо-педагогічній діяльності в ході розв'язання художньо-педагогічних завдань, самостійного конструювання власної художньо-педагогічної діяльності, застосування власних творчих здібностей під час педагогічної практики, що надало респондентам змогу самореалізуватися в позашкільній художньо-педагогічній системі.

Аналіз діяльності студентів засвідчив, що в ході роботи над художньо-творчими завданнями в деяких студентів виникли певні труднощі під час інтерпретації творів образотворчого мистецтва, їм було складно відстежували діалогічні та інтертекстуальні зв'язки в контексті певного живописного полотна, що вказує на низький загальний рівень обізнаності в галузі мистецтва, знань культурно-історичних епох, їхніх представників та провідних пам'яток тощо.

В окремих студентів спостерігалися труднощі 3 організацією педагогічного аспекту художньо-педагогічного процесу. На нашу думку, це зумовлено тим, що в 
навчальних планах художньо-педагогічних спеціальностей більшу кількість годин відведено на фахові дисципліни («Живопис», «Малюнок», «Пластанатомія», «Скульптура», «Робота в матеріалі» тощо), на яких майбутніх педагогів не вчать, як передати набуті знання, оскільки навчальними програмами не передбачено часу на методику викладання певної творчої майстерності, а тим більше в позашкільних установах. А на «Методику викладання образотворчого мистецтва» виокремлено незначну кількість годин, де необхідно спочатку дати загальні відомості 3 теорії навчання, тому що в межах курсів «Педагогіка» та «Психологія» художники-педагоги не отримують цієї інформації (зокрема з методики організації занять різного типу в позашкільних закладах художньо-естетичного напрямку). 3 особливими труднощами студенти зіткнулися в ситуаціях, що передбачали застосування знань 3 вікової психології, оскільки з цим розділом психології вони обізнані не були, а під час роботи в позашкільному закладі це досить суттєвий показник означеної готовності.

Аналіз рівнів сформованості готовності до художньо-педагогічної діяльності в позашкільних закладах освіти художньо-естетичного напрямку студентів мистецьких факультетів експериментальних груп на завершальному етапі відзначається в таблиці істотним відсотковим підвищенням. Так, виявлено небагато студентів, які знаходяться на низькому рівні за всіма критеріями. Незначний відсотковий показник зафіксовано на критичному та низькому рівнях відповідно 7,1 \% та 3,5 \% згідно з експериментальними даними.

Узагальнювальні дані експериментальної роботи з підготовки майбутніх фахівців у галузі мистецтва до художньо-педагогічної діяльності в позашкільних закладах освіти представлено в таблиці 1 .

Таблиця 1

Динаміка готовності фахівців у галузі мистецтва до художньо-педагогічної діяльності в позашкільних закладах освіти (\%)

\begin{tabular}{|l|l|l|l|l|}
\hline $\begin{array}{l}\text { Рівні } \\
\text { готовності }\end{array}$ & \multicolumn{2}{|l|}{ Експериментальна група } & \multicolumn{2}{l|}{ Контрольна група } \\
\hline & $\begin{array}{l}\text { Початок } \\
\text { експерименту }\end{array}$ & $\begin{array}{l}\text { Кінець } \\
\text { експерименту }\end{array}$ & $\begin{array}{l}\text { Початок } \\
\text { експерименту }\end{array}$ & $\begin{array}{l}\text { Кінець } \\
\text { експерименту }\end{array}$ \\
\hline Високий & 10,8 & 28,8 & 10,3 & 9,6 \\
\hline Достатній & 14,8 & 42,6 & 14,3 & 14,9 \\
\hline Середній & 25,7 & 18,0 & 25,1 & 23,4 \\
\hline Критичний & 24,8 & 7,1 & 24,7 & 27,8 \\
\hline Низький & 23,8 & 3,5 & 25,6 & 24,3 \\
\hline
\end{tabular}

Отже, значні зміни студенти експериментальних груп показали за такими критеріями, як мотиваційно-ціннісний і поведінковий, оскільки відстежуються незначні відсоткові показники на критичному та низькому рівнях. Дослідницька робота дозволила окреслити труднощі, з якими стикаються майбутні педагоги-позашкільники в галузі образотворчого та декоративно-прикладного мистецтва під час організації художньо-педагогічної діяльності: невисокий рівень загального інтелектуальнокультурного розвитку, невміння адаптувати художньо-педагогічний матеріал до діяльності в галузі позашкілля, необізнаність 3 методикою організації позашкільної художньо-педагогічної діяльності в художній школі, відсутність знань 3 вікової психології тощо.

Достовірність одержаних нами результатів підтверджено методами математичної статистики. Для порівняння розподілу студентів контрольних та експериментальних 
груп, майбутніх педагогів-позашкільників за рівнями готовності до художньопедагогічної діяльності ми використовували статистичний критерій Пірсона $\chi^{2}$ [4], який дозволяє зіставити два емпіричні розподіли та зробити висновок про те, чи узгоджуються вони між собою. Застосування цього статистичного методу оброблення експериментальних даних зумовлене рівнозначним обсягом вибірки (кількість студентів контрольної та експериментальної груп дорівнює відповідно 58 та 62 особи), кількістю вибірок (дві - контрольна та експериментальна групи), парністю критерію.

Отже, порівняльний аналіз результатів до й після експерименту дозволяє зробити висновок про позитивні результати проведеної роботи. $Є$ вагомі підстави вважати, що рівень підготовки до художньо-педагогічної діяльності в позашкільних закладах художньо-естетичного напрямку в експериментальних та контрольних групах $є$ різним, що узгоджується 3 висунутою гіпотезою про ефективність розроблених та запропонованих умов, їхній позитивний вплив на процес підготовки майбутніх педагогів-позашкільників. Різниця в результатах, отриманих в експериментальних та контрольних групах, підтверджує виправданість запропонованого комплексу умов. Явним стає той факт, що процес підготовки майбутніх фахівців у галузі мистецтва до художньо-педагогічної діяльності відбувається ефективно у зв'язку 3 систематичною роботою і викладачів, і студентів мистецьких факультетів над формуванням означеної готовності. Це доводять показники, отримані в ході формувального експерименту.

Аналіз результатів дослідно-експериментальної роботи дає можливість зробити висновок про можливість та ефективність упровадження запропонованої нами методики підготовки фахівців у галузі мистецтва до художньо-педагогічної діяльності в системі позашкілля. Зіставлення даних констатувального та формувального експериментів доводить ефективність запропонованої нами методики формування готовності фахівців у галузі мистецтва до художньо-педагогічної діяльності в позашкільних навчальновиховних закладах освіти. Це підтверджують статистичні дані: якщо в контрольній групі дані низького рівня фактично не змінилися (25,6 \% на початку експерименту та 24,3 \% у кінці), то в експериментальній суттєво зменшилися (23,8 \% та 3,5\% відповідно); порівняння результатів високого рівня готовності контрольної (від 10,3 \% до 9,6\%) та експериментальної (від 10,8\% до 28,8 \%) груп свідчить про результативні зміни в експериментальній групі.

Перспективною залишається проблема підготовки фахівців у галузі мистецтва до різних видів художньо-творчої діяльності в позашкільних закладах освіти художньоестетичного спрямування.

1. Биковська О. В.

Позашкільна освіта :

теоретико-методичні основи : [монографія]/ О. В. Биковська. - К. : ІВЦ АЛКОН, 2008. - 336 с. 2. Прокофьева И. В. Формирование готовности студентов вузов искусств и культуры к художественно-педагогической деятельности : автореф. дис. на соиск. научной степ. канд. пед. наук : спец. 13.00.01 «Общая педагогика, история педагогики и образования» / И. В. Прокофьева. - Тюмень, 2002. - 24 с. 3. Сущенко Т. I. Позашкільна педагогіка : [навч. посіб.] / Т. І. Сущенко. - К. : КДО, 1996. - 144 с. 4. Полонский В. М. Оценка качества научно-педагогических исследований / Полонский В. М. - М. : Педагогика, 1987. - 334 с. 5. Філіпенко А. С. Основи наукових досліджень: Конспект лекцій / Філіпенко А. С. - Київ : Академвидав, 2005. - 230 с. 